\title{
Designing an English Syllabus for Nursing Students based on Need Analysis in Indonesia
}

\author{
D e d i \\ dedibae85@gmail.com \\ Graduate Program \\ State University of Makassar, Indonesia
}

\begin{abstract}
This paper aims to figure out (1) the learners learning needs, (2) the learners language needs and (3) to design a suitable syllabus of English based on the learner's need. This research applied descriptive quantitative method. There were some techniques used for taking the sample. They are convenience sampling and purposive sampling. There were two groups of the subjects in this research. They were the nursing students of Stikes Mega Buana Palopo and graduate students who work in Hospital Sawerigading Palopo. This result of this research showed that (1) learning needs where consist of the skills of language and preferences of learning. In term of skills of language, the skills of language are used at the often category for students in the classroom. In learning English with other learners, pairs study is preferred than study alone, and study in small group is more preferred than study in big group meanwhile preferences of learning in terms of using teaching techniuqe, learn by pronouncing and listening, and use fun activity, role play are preferred by the learners. (2) the needs of language consist of English use in workplace. Regarding to use English in workplace, the graduates students hardly ever speak English in hospital. In language function, regarding to graduates' perspective about language function, all the categories fall into important level that used in hospital. (3) The syllabus design was regarding to the learners' need where includes topic, function of language, strategies of language, strategies of teaching and focus of language.
\end{abstract}

Keywords: Need analysis, Syllabus, Teaching Materials, Learning Needs, Learning Style, Language Function, Teaching Strategies, and Language focus.

\section{INTRODUCTION}

Need Analysis serves as the basic of programs of development and programs of training. It is the first step of ESP and guid to focuse of the subject. To analyze the needs of particular students group serves as an important starting point in design of ESP for determining the main and the highlight the reasons of the ESP. It is able to assist to choose and prioritize what students need. Besides, the aim of ESP is to make the students able to the language of use appropriately. ESP is to design to identify who is the target and deliver the analysis of the linguistic completely. This process is termed as TSA (Hutchinson \& Waters, 1987).

dr. Ishak Iskandar (2016) stated that, the number of nurses in Palopo that unemployed above 3.500, not including around 500 nurses who work as volunteer in hospital Sawerigading Palopo and other health center. He said that the high rate of unemployement nurse because almost every year Nursing School in palopo graduated 
their students so that's why the number of unemployemet nurses add every year. In 2015, Palopo only accept 4 nurses for the civil servant but the applicants above 3.500 people. The government has taken steps to solve this problem by sending those 'surplous' nurses abroad as there is high demand of nurses in malaysia, singapore, brunei darussalam, qatar, kuwait, japan, dutch, australia, and united state. Unfortunetaly, 25\% of total applicants could be accepted. One of their weaknesses in the test requirement is their mastery of English.

The problems above are affected by some factors, the first, the department adopted English syllabus from English language teaching department and from English Course. The syllabus that they adopted is structural syllabus which had different goals and objective with the students of nursing students.The second, the lecturers do not have capacity in developing English syllabus for nursing students. The third, the lecturers use different materials in different resources applied in the class. In teaching the materials, the lecturer focuses on grammatical point of view such as tenses, parts of speech, sentences, phrases, clauses WH-questions and so on. It can be taken from internet, newspapers, or magazines. It is often encountered that the materials taken from internet, newspapers, or magazines are ready made materials. Those materials come from different sources is not appropriate with students need.

Furthermore, Rany (2013) found that the students are weak in mastering English language because the teachers of English are not trained well, the foundation of the students English background, the learners hesitate to use English because they have high anxiety in speaking English, the students considered if English is quite difficult to learn because they are not motivated well, less spirit and the way of teacher teaching them less of the strategies. Many students never practice their English skills especially in speaking skill. They are afraid of making mistakes when practice their English so that's why their skill will not increase. Moreover, the place of studying is not suitable for them because most of the class situation is noisy. The most important thing is the curriculum is not suitable with students needs.

Regarding to rational explanation above, the researcher would like to formulate research question as follow: (1) What are the learning needs of the Nursing students at Stikes Mega Buana Palopo? (2)What are the language needs of Nursing students at workplace? (3) What are the suggested syllabus for students at stikes Mega Buana Palopo? The objectives of this paper were formulated to find out: (1) To identify the learning needs of the students of Stikes Mega Buana Palopo, (2) To identify the language needs of the students in the workplace, (3) To design an appropriate syllabus for nursing students of Stikes Mega Buana Palopo.

\section{REVIEW OF LITERATURE}

\section{Related studies}

The importance of identifying needs analysis is to provide useful information to improve the English teaching quality has been conducted by some researchers. Mulyani (2013) conducted the research to find out whether or not the English teaching materials given at nursing college students to fulfill the nursing English needs at work and to find out the English teaching materials that suitable the needs of nursing students. The result of this research showed that the students needed nursing English teaching materials which consisted of both general English and medical/ nursing English by nursing demonstration 
practice as the methodology in English teaching. The result also indicated that speaking was the most important skill in studying nursing English teaching material.

These findings indicated only the students' needs in different skills of English language teaching. The researchers did not include the syllabus design which are relevant to the students' perceptions. While, the writer of this research included the syllabus design that based on the students' need.

Similarly, Alinezhad and Gholami (2012) conducted a research with the aim to investigate the English Language needs of nursing students during their education, and nursing practitioners in the workplace (in Urmia). The result of this research indicated that English knowledge was really influential in participants' academic life and in professional life. While, Freihat and Al-Makhzoomi (2012) conducted a study to explore the learning needs of nursing students in Jordan. The researcher used three procedures; interview, observation, and questionnaire. The researchers found that the participants have difficulty in communicating with clients in the various clinical settings, inability to follow through with step-by-step procedures, difficulty charting or documenting appropriately in clients' records, and accidentally misread the numbers written on the physician's orders. In the researchers' view, both social English and ESP enable nursing students to communicate in English with clients, collegues and nursing supervisors of culturally and linguistically diverse backgrounds and enrich them as individuals.

Hwang and Lin (2012) conducted a study to provide a description of the linguistics needs and perceptions of medical students and faculty members in taiwan. They concluded that this research could analyze the linguistics needs of interns and suggested to improve the English curriculum for the School of medicine, and other assistance or requirements for medical students' linguistics needs.

Their findings identified English knowledge was really influential in academic and professional life. Both social and ESP enable the students to make communication with others of culturally and linguistically diverse background and enrich the students as individuals. They suggested that in designing the English language course, ESP teachers should take into consideration learners' needs by focusing on all the language skills, with greater emphasis on speaking and listening.

All of the research findings above are mainly on needs analysis in terms of providing useful information to improve the English language teaching quality from both sides, the students and teachers side. These findings could encourage the other researchers to design of the course or the syllabus based on the researcher findings.

\section{Theoritical background}

\section{English for Specific Purposes (ESP)}

In order to define what ESP is, Streven (1988) defines ESP by making a distinction between absolute characteristics and two variable characteristics. Absolute characteristics get in touch with designing language teaching $\mathrm{d}$ in order to fulfill the specified needs of the students in contrast, ESP dealing with the two variable characteristics focuses more on learning restricted language skills such as focusing more on learning reading or speaking. The skills being taught depend on the learners' purposes in which some learners 
only want to learn speaking, for example, in order to improve their speaking abilities. Then, Robinson (1991: 3) defines ESP in two parts. First, he views ESP as normally" goal- directed'. It designed in order to get your own in touch with particular goals of the learners. Second, he views that if ESP is made as the base in need analysis for homogenous classes. It means that it should indicate what exactly the learners must do on their medium English in short time to achieve their objectives. Finally, Fiorito (2005) affirms that ESP students are usually adults who already have some acquaintance with English and are learning the language in order to communicate a set of professional skills and to perform particular job- related functions.

\section{Need Analysis}

Dudley-Evan defines a need analysis as establishing process how and what for a subject. Regarding to need analysis in ESP covered;

a. TSA (Target Situational Analysis) and objective needs are to get information about the students, the assignment and the students activity.

b. Wants, means, subjective needs are the figure out the information about the students, some factors that influence their learning style, such as their past experience in studying, their culture information, some reasons for coming to the course and their expectation on it.

c. PSA (Present Situational Analysis) is the analysis technic to find out about the information of language of the students, such as what the current skill that they have.

d. Lacks is the need analysis about the gap between (c) and (a).

e. Learning needs is the need analysis about the information of the students in terms of the appropriate ways in learning skills and language in (d).

f. Lingustics analysis, discourse analysis, and genre analyisis are the need analysis to get the information about (a) the language and skills are used in target situation.

g. Means analysis is to get information about the surrounding where the course will be carried out.

\section{Syllabus}

In regard of what syllabus is, some people have already define it dealing with their own perspective. Rabbini \& Gakuen (2002) defines a syllabus as an expression of opinion on the nature of language and learning to be attained. In this case, they view syllabus as a set of the idea for teaching in which it will be a guide for both teacher and learner by providing some goals or objectives of the teaching and process of learning. Besides that, it seems like a map for the teachers in which they will see the map as their instruction when they stray away in teaching.

Furthermore, MacKey (1979) : states that a syllabus provides a focus for what should be studied, along with a rationale for how that content should be selected and ordered. In addition, Yalden (1987: 87) affirms that a syllabus can also be seen as a summery of the content to which learners will be expected. It is also consistent with Crombie (1985) in which he also defines syllabus as a list or inventory of items or units with which learners are to be familiarized. In this case, McKey, Yalden and Crombie have the same point of view in defining syllabus in which they emphasize a syllabus as a set of materials that should be covered or included in the syllabus. 


\section{Component of Syllabus}

Commonly, a good syllabus will account for at least five components. First, the goals and objectives of the topic: Brown (1995: 71-73) Defines goals as general statements about what must be accomplished in order to attain and satisfy students' need. The aim of stating goals are to: a) Provide clear objective of a program, b) provide guidlines for teachers, c) Help provide a focus on instruction, and d) Describe important and realizable changes in learning. In contrast, the instructional objective is specific statements that the learners will be expected to get and understand after following the course. The characteristics of instructional objectives are to : a) Describe the goal/ aim in smaller units or learning, b) A basis for organization of activities, and c) Describe learning in terms of observable behaviour of performance.

Second, the teaching materials and media teaching materials deal with what material being taught to the learners during the course. The materials should be in line with the learners' needs and interests. It also deals with the goals and the aims of the topic. In contrast, media deals with the media used in teaching and learning process in order to help the teachers to accomplish the goals and objectives of the course. It accounts for books, whiteboard, LCD, Computer/Laptop, disks, CD-Rom's, flash drives, lab supplies and so forth.

Third, the teaching and learning activities: it deals with what strategies being implemented in the teaching and learning activities such as discussion, role-play, presentation, lecture, service learning, cooperative learning, group projects, group grades, peer evaluation, practicum, and so forth.

Fourth, assessment: it deals with how to evaluate the teaching and learning processes. It accounts for assignments, weight of each assignment of exam, kinds of papers of project, format, due dates, kinds of exams due dates, reading assignments, rewrite and make-up policies, acceptability of handwritten work, grading criteria, and policy on late assignments, fifth, time allotment: it deals with the duration of each material being taught, or how many meetings for each material.

There are several types of syllabus that can be adapted into new syllabus design. Wilkins (1981) proposed two kinds of syllabus: situational syllabus and notional syllabus. Situational syllabus is created to replace the grammatical syllabus. It is used as a basis for the construction of teaching materials and units in the syllabus have situational instead of grammatical labels. The notional syllabus takes the communicative capacity as the starting-point.

\section{RESEARCH METHODOLOGY}

This research applied a descriptive quantitative design. According to Gay, et al. (2006), this type of design relates to collection, analysis and interpretation of comprehensive, narrative and visual data in order to gain insight into a particular phenomenon of interest. It is also referred to a survey research, determines and describes the way things are. The researcher analyzed, described and interpreted quantitative data.

The subject of this research were the students and graduates of Stikes Mega Buana Palopo. The subject were taken from two groups. The first group was the students who 
were still studying in campus of Stikes Mega Buana Palopo. There were 21 students of the third semester of Students who were taken as the sample of this group. The second group were 5 graduates Students who worked as volunteer nurse in hospital Sawerigading Palopo. The researcher used convenience sampling for nursing graduates students whoever avalaible at the time.

The researcher used interview and questionnaire as the instrument. The questionnaire gave to 21 students who were still studying at the Campus and 5 graduates who worked in Hospital Sawerigading Palopo. The interview has been given for both students and graduates, where the researcher chosed 5 students who were still studying and chosed 2 graduates students randomly. The interview test was to support the data from questionnaire. The questionnaire used to identify the students' need in nursing English teaching material and to design appropriate syllabus.

The procedures of data collection of this research were described as follows: (1) The first research question, the researcher interviewed and distributed questionnaire to the nursing students to find out their learning needs. (2) The second research question, the researcher interviewed and distributed questionnaire for graduates who work in hospital sawerigading Palopo and Campus Stikes Mega Buana to find out their language needs. (3) The third research question, the researcher designed syllabus based on the students' learning and language needs.

The data from the interviews and questionnaires were analyzed by descriptive quantitative. For the first and second research questions, the data form the respondents' questionnaire were analyzed by looking for the average score of each number, while the data from the interview was transcribed. For the third researh question, the researcher designed and provided materials based on the students' need.

\begin{tabular}{|c|c|c|c|}
\hline Score & Frequency level & Importance level & Difficult level \\
\hline 1 & Hardly ever & Not important & Not difficult \\
\hline 2 & Seldom & Less important & Less difficult \\
\hline 3 & Often & Important & Difficult \\
\hline 4 & Always & Very important & Very difficult \\
\hline
\end{tabular}

The average score will be obtained by Add all score in the same answer within one number of questionnaires to get the frequency, then divided it with the total participants or subject, to get the percentage multiplied it with $100 \%$.

\section{FINDINGS AND DISCUSSION}

\section{Findings}

\section{The frequency of using English in the classroom}

Based on the result of questionnaire given to the students about the frequency of using English in the classroom, the table 4.1 shows the total and the mean scores for all the language skills (listening, speaking, reading, and writing) are used at the rate of often categorized. Listening (2.6) writing (2.5), and reading (2.5) are used more often than Speaking (2.3) in the classroom. 
Table 4.1 The Frequency of Using English in the Classroom

\begin{tabular}{lcc}
\hline Skill & Total & Mean score \\
\hline Listening & 55 & 2.6 \\
Speaking & 49 & 2.3 \\
Writing & 52 & 2.5 \\
Reading & 52 & 2.5 \\
\hline
\end{tabular}

\section{The difficulties of language skills used by the students}

Based on the result of questionnaire given to the students about the difficulties of using English skills in the classroom, the table 4.2 below shows the total and the mean scores for all the language skills, for speaking, writing, and reading are used at the rate of less difficult categorized while for listening was used at the rate of not difficult.

Table 4.2 The Difficulties in Learning English

\begin{tabular}{lcc}
\hline Skill & Total & Mean score \\
\hline Listening & 38 & 1.8 \\
Speaking & 55 & 2.6 \\
Writing & 46 & 2.1 \\
Reading & 46 & 2.1 \\
\hline
\end{tabular}

\section{The importance of language skills}

The four English skills are very important for the students. Regarding that those language skills are integrated skills, they cannot be seperated. Such as speaking skills cannot be seperated from listening skill, and writing skill cannot be seperated from reading skill. Based on the result of questionnaire given to the students about the The Importance of Language Skills in the classroom, the table below shows the total and the mean scores for all the language skills (listening, speaking, writing, and reading) fell into important category.

Table 4.3 The Importance of Language Skills

\begin{tabular}{lcc}
\hline Skill & Total & Mean scores \\
\hline Listening & 67 & 3.1 \\
Speaking & 74 & 3.5 \\
Writing & 67 & 3.1 \\
Reading & 66 & 3.1 \\
\hline
\end{tabular}

\section{Learning and Teaching Activities that Mostly Preferred}

Learning preferences is about on how the students learn well and like the teaching activities or technique used by the teacher, and how the students select the appropriate materials theat serve the students' need in learning. Based on the result of questionnaire given to the students about the important of learning methods and activities in learning English, the table 4.8 below shows the total and the mean scores for all the items. 
Table 4.4 Learning and Teaching Activities that Mostly Preferred

\begin{tabular}{lcc}
\hline & Total & $\begin{array}{c}\text { Mean } \\
\text { score }\end{array}$ \\
\hline 1. Self study & 57 & 2.7 \\
2. Study in pairs & 61 & 2.9 \\
3. Study in small group & 62 & 2.9 \\
4. Study in big group & 57 & 2.7 \\
5. Study through listening & 65 & 3.1 \\
6. Study through reading & 64 & 3 \\
7. Study through listening and pronouncing & 72 & 3.4 \\
8. Study through repetition of what is heard & 70 & 3.3 \\
9. Study through memorizing and conversation & 69 & 3.2 \\
10. Study through games & 59 & 2.8 \\
11. Study through role play & 59 & 2.8 \\
& & \\
\hline
\end{tabular}

Each students about learning preferences and teaching activities are different. Learning preferences in terms of studying with others, it has been found that study in pairs (2.9), and study in small group (2.9), which categorized as important ways of learning. Self study (2.7) and study in big group $(2,7)$ which fallen into important level. These findings indicate that study in pairs, seelf study, and in a small group should be taken into consideration in creating the activities to fullfill the learning preferences in learning English for nursing.

Not only identifyinng the learning preferences in terms of the ways of learning with others, but also it is important to find out the students learning preferences in terms of the ways of learning by using the teaching equipment. As we can see on the table from students' answer, it shows that study through listening while pronouncing $(3,4)$ fall into very important category. This finding indicates that study through listening while pronouncing is more preferred than others such as study through reading,study through listening, study through repetition, and study through memorizing and pronouncing which are categorized as the important ways of learrning.

In addition, that teaching English by using role plays and games are preferred in learning English. Study through game $(2,8)$ and study through role play (2.8) fall into important category should be taken into consideration in designing syllabus.

\section{The Language Function Needed by the Students in the Classroom}

The language needed by the students in the classroom is about the appropriate topic and learning material that fit for the nursing students need. The frequency and the percentage of the students' responses for each item of the questionnaire related to the language function needed by the students in the classroom can be seen in the following table; 
Table 4.5 The Language Function Needed by the Students in the Classroom

\begin{tabular}{lcc}
\hline \multicolumn{1}{c}{ Language Skills } & Total & $\begin{array}{l}\text { Means } \\
\text { Score }\end{array}$ \\
\hline 1.Patient admission form & 60 & 2.9 \\
2.Prescription/ instruction to use drugs & 74 & 3.5 \\
3. Greet/welcome the patients & 66 & 3.1 \\
4.Explaining the events that occur to patients & 65 & 3.1 \\
5.Telling routine and recent activity & 55 & 2.6 \\
6.Caring for patients after surgery & 62 & 2.9 \\
7.Showing direction & 62 & 2.9 \\
8.Asking and giving instruction & 64 & 3 \\
9.Asking, giving recomendation, and prohibition & 64 & 3 \\
10.Asking and giving suggestion & 63 & 3 \\
11.Mention kinds of disease & 61 & 2.9 \\
12.Explain the parts of body & 59 & 2.8 \\
13.Telephone & 51 & 2.4 \\
14.Explain the medical tools & 70 & 3.3 \\
\hline
\end{tabular}

From the table 4.5 above, we can see the total and means score about the questionnaire based on the language function needed by the students in the classrroom. The language function needed by the students in the classrom fall into important category such as writing about the patient admission form, writing prescription, listening to the converastion, talking about instruction, taking care patients post operation, showing direction, asking and giving instruction and expression, telling the kinds of disease, telephone skills, and explaining drugs interaction. welcoming the patients, asking and giving appropriate suggestion and advice.

\section{The Importance of Language Skills}

The frequency and the percentage of the students' responses for each item of the questionnaire can be seen in the following table;

Table 4.6 The Importance of Language Skills

\begin{tabular}{lcc}
\hline & Total & Mean score \\
\hline To be succes in college & 72 & 3.4 \\
To continue the study & 73 & 3.5 \\
To be success in carrier & 74 & 3.5 \\
To exchange information & 72 & 3.4 \\
To get scholarship & 72 & 3.4 \\
As personal need & 72 & 3.4 \\
\hline
\end{tabular}

Furthermore, regarding to the importance of English, most of the students take into account that English is very important to be success in carrier $(3,5)$, to get scholarship $(3,4)$ and to continue the study $(3,5)$, while some of the students stated that to be success in college $(3,4)$, as tool to exchange the information $(3,5)$, and as personal need $(3,4)$ taken into important level. 


\section{The frequency using language skills in the workplace}

This part shows the use of English language in the workplace from graduates perspective. From graduates' questionnaire, they mentioned that speaking (2.2) is used at the rate of seldom, while listening (2.6) is used at the rate of often, writing (2.4) fall into seldom categorized, and reading (2.4) is seldom used in the workplace. As the following table:

Table 4.7 The Frequency of Using Language Skills in the Workplace

\begin{tabular}{lcc}
\hline & Total & Mean score \\
\hline Listening & 13 & 2.6 \\
Speaking & 11 & 2.2 \\
Reading & 12 & 2.4 \\
Writing & 12 & 2.4 \\
\hline
\end{tabular}

\section{The use of English in workplace}

In terms of using English in the workplace, the graduates who work in hospital Sawerigading Palopo stated that they hardly ever speak English with native speaker on non native speaker, and they hardly ever communicate in English with Indonesian people and with their co worker. Furthermore, English is hardly ever used in conversation, from all the questionnaires that gave to graduates, the total and the mean scores of the questionnaires at the rate of hardly ever. As the table below:

The table 4.8 : The Use of English in the Workplace

\begin{tabular}{lcc}
\hline & Total & Means score \\
\hline Do you speak English with native? & 5 & 1 \\
Do you speak English with non native speaker? & 8 & 1.6 \\
Do you speak English with Indonesian people? & 9 & 1.8 \\
Do you speak English with patient in your & 8 & 1.6 \\
workplace? & & \\
Do you speak English with your co worker? & 9 & 1.8 \\
Do you communicate in English with face to face? & 9 & 1.8 \\
Do you communicate in English by phone? & 5 & 1 \\
Do you communicate in English by email? & 8 & 1.6 \\
\hline
\end{tabular}

\section{The difficulties in learning English}

Regarding to the difficulties faced by the students in learning English, from the graduates' questionnaire, it has been found that listening (3.2) and speaking (3.4) are in difficult category, while writing (3.5) is in very difficult category, and reading (2.6) fall into less difficult for them, as seen in the table;

Table 4.9 The Difficulties in Learning English

\begin{tabular}{ccc}
\hline Skill & Total & Mean score \\
\hline Listening & 16 & 3.2 \\
Speaking & 17 & 3.4 \\
Writing & 18 & 3.5 \\
Reading & 5 & 2.6 \\
\hline
\end{tabular}

The Important of English 
Furthermore, from graduates' view, English is at the rate of very important to be success in carrier (4), as a tool to exchange the information (4), and to get a scholarship (4), and less important as personal need (4).

Table 4.10 The Importance of English

\begin{tabular}{lcc}
\hline & Total & Mean score \\
\hline To be success in carrier & 20 & 4 \\
To exchange information & 20 & 4 \\
To get scholarship & 20 & 4 \\
As personal need & 20 & 4 \\
\hline
\end{tabular}

\section{The language function used in the workplace}

English language functions play an important role to make the students function adequately in the target situation. Here are the language functions that are mostly required in by the graduates in the workplace.

From graduates' perspective on the table, it shows that welcoming the patients (3) and asking and giving appropriate suggestion and advice (3) are into important category, while writing about patient admission form (3), talking about the instruction (3), asking and giving instruction and expression (3), asking and givin recommedation and prohibition (3), telling the kinds of disease (3) and telephone skills (3) fall into important level, and taking care the patients post operation (3) and showing direction (3) categorized as important. As the following table:

Table 4.11 The Language Function Used in the Workplace

\begin{tabular}{lcc}
\hline & Total & $\begin{array}{c}\text { Mean } \\
\text { score }\end{array}$ \\
\hline Filling in the patient admission & 15 & 3 \\
Prescription & 15 & 3 \\
Conversation & 15 & 3 \\
Welcoming the patient & 15 & 3 \\
Instruction & 15 & 3 \\
Taking care the patients post opearation & 15 & 3 \\
Showing direction & 15 & 3 \\
Asking and giving instruction and expression & 15 & 3 \\
Asking and giving recomendation and prohibition & 15 & 3 \\
Asking and giving appropriate suggestion and advice & 15 & 3 \\
Telling the kinds of disease & 15 & 3 \\
Telling blood systems & 15 & 3 \\
Telephone skills & 15 & 3 \\
Explaining drugs interaction & 15 & 3 \\
\hline
\end{tabular}




\section{DISCUSSION}

As a problem statement showed above, three research questions that will be answered, they are the learning need of students and graduate students, syllabus and materials design.

For the learning need, the researcher found that learning preferences and teaching activities should be considered in teaching and learning process. Learning preferences regarding to the ways of learning with others, the researcher conluded that if study in pairs, self study and study in a small group are more preferred than studying in a big group.

In learning activities, both the students and graduates stated that studying through listening, studying through reading, studying through listening and speaking, and learning through repetition of what is heard are preferred. Furthermore, according to the respondents, learning English by using games and role plays should be taken into account when designing syllabus and the researcher also found that the most interesting teaching technique or strategy based on the students' views are studying through picture which is displayed on the screen by LCD and has meaning (for instance in showing the medical equipments and its fucntion), games, and communicative activities, so the students can practice it directly with their friends, either in pairs or in a group.

For the second research question, the researcher found that listening, speaking, writing, and reading are used at the rate of seldom in the workplace. Those English skills are seldom used by the graduates students because most of the patient or their co-worker in Hospital Sawerigading Palopo don't used English as their communication in the workplace. However, based on the important English for graduates such as, to succeed in carrier, for information exchange, to get scholarship, and for personal need are at the rate of very important. This means that the language needs needed most by the graduates are the skills in English (speaking, listening, writing, and reading). By considering these findings, the language activity that might be basic for the nursing learners are greetings about how to greet and asking as to the information about the patients. Other language activities such as conversation between nurse and patient, welcoming the patient, taking blood pressure, giving suggestion and advice, and hospital admission can also be considered in designing the syllabus.

In terms of language function, the researcher found that the students need to learn some kinds of expressions such as greetings (welcoming the patients), giving direct instruction to the patients, asking and giving instruction and expression, asking and giving appropriate suggestions and expressions, asking and giving appropriate suggestion and advice, telling the blood systems, telling kinds of disease, write about patients admission form, writing reports, and showing direction in order that the students are able to master and apply all of the English skills adequately in the target situation.

After analysing the students' learning and language need and based on the general task of nursing, the researcher suggests that a syllabus used by the Lecturers in teaching nursing students should include topics, language functions and focus, English focus skills, competence and teaching strategies and of course it should be based on the students' needs, so in this case, functional/notional syllabus is suitable for nursing students. 


\section{CONCLUSION AND SUGGESTION}

\section{Conlusions}

Based on the findings and the discussion, the research put the conlusion of this research.

The needs of the students comprise of learning need and language need. Learning needs include; language skills and learning preferences. In terms of language skills, listening, speaking, writing, and reading are used often in the classroom which is supported from the questionnaire and interview. While in the workplace all the four language skills; listening, speaking, writing, and reading are used seldom. but based on the importance of English, the graduates students who work in hospital relized that if English is very important for their carrier, to get more information, to get scholarship, and as personal need which is supported from interview and questionnaire. The language skills needed for both the students and the graduates are the four skills of English; listening, speaking, writing, and reading, that means in the learning process, the lecturer needs to give more proportion in the four skills and give more rehearsal to the students.

In terms of using English in the workplace, the graduates who work in hospital Sawerigading Palopo stated that they hardly ever speak English with native speaker or non native speaker, and they hardly ever communicate in English with Indonesian people and with their co worker. Furthermore, English is hardly ever used in conversation, from all the questionnaires that gave to graduates, the total and the mean scores of the questionnaires at the rate of hardly ever. but based on the importance of English, the graduates students who work in hospital relized that if English is very important for them which is supported from interview and questionnaire. The language skills needed for the graduate students are the four skills of English; listening, speaking, writing, and reading. While about the language function such as greetings, giving direction, and asking and reporting health problems and diagnosing.

From the needs of the students, language need and learning need, the syllabus should include topics, language functions, language focus, skills, competence and teaching method and it should be based on the student's needs, so in this case, based on the explanations about general task of Nursing then fucntional/notional syllabus is suitable for nursing students.

\section{SUGGESTIONS}

Based on the conclusion above, researcher present the following suggestions that addressed to people who concern with this research topic, they are: 1) Curriculum designers of nursing subjects, particularly in nursing English curriculum, who should evaluate the adequacy of the existing syllabus, materials, and create a new syllabus and materials that based on the students need. 2) Nursing instructors of teachers need to find out interesting ways in teaching English . 3) It is suggested also that the English teaching materials should be based on the student's need.

\section{REFERENCES}

Alinezhad, Gholami, Javad. 2012. English Language needs analysis of nursing students and nursing practioners in Urmia. International Journal, Vol. 2, No. 7. 
Dedi: Designing an English Syllabus for Nursing Students ...

Brown, J. D. 1995. The of Language Curriculum. Massachusetts: heinle \& Heinle Publishers.

Chambers, F. 1980. A re-evaluation of needs analysis. ESP Journal, 1/1, pp. 25-33.

Crombie, W. 1985. Discourse. And language learning: a relational approach to syllabus design. Oxford: Oxford University Press.

Carver 1983 Developments in English for specific purposes- a multi-disciplinary approach. Cambridge: Cambridge

Dudley-Evans Tony and Maggi Jo St. John. Developments in English Teaching for Specific Purpose. A multy-discplinary approach. Cambridge: Cambridge UP, 1998.

Fiorito, L. 2005. Teaching English for specific purposes (ESP) (Online), http://www.usingEnglish.com/articles/teaching-English-for-specific-purposesesp.html, retrieved October 25th, 2012.

Freihat, Saleh and Al-Makhzoomi, Khalaf. 2012. An English for specific purposes (ESP) course for Nursing Students in Jordan and the role a needs Analysis played. Internatioanl Journal of Humanities and Social Science, Vol.2 No.7.

Gay, et al. 2006. Second Language Writing. Cambridge: Cambridge University Press.

Hwang, Yanling and Lin, Siouzih. 2012. A study of medical students' linguistic needs in taiwan. International journal of ESP.

Iwai, T., Kondo, K., Limm, S. J. D., Ray, E. G., Shimizu, H., and Brown, J. D. (1999). Japanese language needs analysis. Available at: http://www.nflrc.hawaii.edu/Networks/NW13/NW13.pdf

Krahnke, K. 1987. Approaches to Syllabus Design for Language Teaching. Englewood Cliffs: Prentice hall Regents.

MacKey,R. 1979. English for Specific Purpose: A Case Study Approach. London: Longman

Parkes, J. \& Harris, M. B. 2002. The Purpose of a Syllabus. College Teaching, 50 (2), 55-61. In the Teaching Professor, January 2003.

Rabbini, R. \& Gakuen, B. 2002. An Introduction to Syllabus Design and Evaluaiton. The Internet TESL Journal, vol. VIII, No. 5, may 2002, retrieved from http://iteslj.org/Articles/Rabbini-syllabus.html, on september 25th, 2012.

Rany et al. 2013. Developing A Proposed Syllabus of EAP Reading for the Medical students of Barawijaya University. Unpublished Thesis the Degree of Master of English Language Teaching. Malang: State University of Malang.

Richterich \& Chancerel 1980. ESP (English for Specific Purposes). New York: Pergamon.

Wilkins D.A. 1981 "Notional Syllabuses Revisited" Applied Linguistics, volumeII, Number1, Spring, 1980

Yalden, J. 1987. Principles of Course design for Language Teaching. Cambridge: Cambridge University Press. 